\title{
ANALISIS LITERASI KEUANGAN PEDAGANG DI PASAR OESAPA KOTA KUPANG - NUSA TENGGARA TIMUR
}

\author{
Voldiana Sine ${ }^{1}$,Pius Bumi Kellen², Paulina Y. Amtiran ${ }^{3}$ \\ 1,2,3 Universitas Nusa Cendana, dianasine14@gmail.com, Pius0309@gmail.com, \\ yurithafunkq@gmail.com
}

\begin{abstract}
ABSTRAK
Penelitian ini bertujuan untuk mengetahui tingkat literasi pedagang di Pasar Oesapa. Metode yang digunakan dalam penelitian ini adalah metode survei dengan pendekatan deskriptif kuantitatif. Penelitian ini menggunakan empat indikator untuk mengukur literasi keuangan. Keempat indikator tersebut yaitu Pengetahuan Keuangan, Perilaku Keuangan, Sikap Keuangan dan Tanggapan Teknologi Perbankan. Populasi dalam penelitian ini merupakan seluruh pedagang di Pasar Oesapa dan sampel dalam penelitian sebanyak 90 responden dari keseluruhan populasi. Data primer diperoleh dengan kuesioner dan wawancara langsung dengan responden. Hasil penelitian ini menunjukkan bahwa pengetahuan keuangan, perilaku keuangan dan sikap keuangan pedagang di Pasar Oesapa berada pada tingkatan sedang sedangkan untuk tanggapan Teknologi Keuangan berada dalam kategori rendah. Secara keseluruhan tingkat literasi keuangan pedagang Oesapa berada pada kategori sedang yang berarti pedagang di Pasar Oesapa hanya memiliki pengetahuan dan keyakinan terhadap lembaga keuangan namun belum memiliki keterampilan untuk menggunakan produk/jasa lembaga keuangan.
\end{abstract}

Kata Kunci: Literasi Keuangan, Produk Keuangan, Pengetahuan Keuangan, Perilaku Keuangan, Sikap Keuangan dan Teknologi Perbankan

\begin{abstract}
This research aims to analyze the literacy levels of Oesapa Market traders. This research is a quantitative descriptive by using survey method. There are four indicators that used in this research, that indicators are Financial Knowledge, Financial Behaviour, Financial attitudes and Banking Technology. The population in this study was all traders in Oesapa Market and the sample in the study were 90 respondents from the entire population. Primary data were obtained from respondents by using questionnaires and direct interview with each respondents. The result of this research shows that literacy level of Oesapa Market traders be in moderate level which is for financial knowledge, financial behaviour and financial attitude be in moderate level, while banking technology conception in low levels. But for totality literacy level is moderat, it means that Oesapa Market traders have a knowledge and belief to Financial institution but they are not skilful to use products/services of financial institution.
\end{abstract}

Keywords: Financial Literacy, Financial Products/Services, Financial Knowledge, Financial Behaviour, Financial Attitude and Banking Technology.

Naskah diterima : 02-07-2020, Naskah dipublikasikan : 30-09-2020 


\section{PENDAHULUAN}

Pemahaman tentang literasi keuangan saat ini perlu dikembangkan terutama di Indonesia, dikatakan demikian berdasarkan survei yang dilakukan Bank Dunia tahun 2010 menunjukkan bahwa separuh penduduk Indonesia tidak memiliki akses atas layanan lembaga keuangan formal. Hal ini mengindikasikan bahwa sistem keuangan belum berjalan secara optimal serta masih adanya ruang untuk perbaikan dalam rangka peningkatan lembaga keuangan (GPKI-DPAU,2014). Menindaklanjuti hal tersebut, maka pada Juni 2012 Bank Indonesia bersama pemerintah mengeluarkan Strategi Keuangan Inklusif dengan visi utamanya adalah mewujudkan sistem keuangan yang dapat diakses oleh seluruh lapisan masyarakat untuk mendorong pertumbuhan ekonomi, penanggulangan kemiskinan, pemerataan pendapatan dan terciptanya stabilitas sistem keuangan di Indonesia. Salah satu pilar utama untuk mewujudkan visi tersebut adalah Edukasi Keuangan. Edukasi keuangan bertujuan untuk meningkatkan pengetahuan dan kesadaran keuangan masyarakat atau biasa disebut financial literacy.

Organization for Economic Co-operation and Development (OECD) mendefinisikan literasi keuangan sebagai pengetahuan dan pemahaman atas konsep dan risiko keuangan, berikut keterampilan, motivasi, serta keyakinan untuk menerapkan pengetahuan dan pemahaman yang dimilikinya tersebut dalam rangka membuat keputusan keuangan yang efektif, meningkatkan kesejahteraan keuangan (financial well being) individu dan masyarakat, dan berpartisipasi dalam bidang ekonomi (SNLKI, 2017).

Data Bank Dunia tahun 2011, menemukan bahwa literasi keuangan Indonesia sebesar 20 persen. Bank Dunia menyebutkan bahwa tingkat literasi keuangan Indonesia terendah di kawasan Asia Tenggara. Untuk meningkatkan tingkat literasi keuangan Indonesia, maka pada 19 November 2013 pemerintah Indonesia mengeluarkan Strategi Nasional Literasi Keuangan Indonesia (SNLKI). Strategi Nasional tersebut mencakup tiga pilar utama yaitu edukasi dan kampanye nasional literasi keuangan, penguatan infrastruktur literasi keuangan dan pengembangan produk dan jasa keuangan. Penerapan ketiga pilar SNLKI ini diharapakan mampu menciptakan masyarakat Indonesia yang memiliki literasi keuangan yang tinggi.

Hasil yang diungkapkan berdasarkan SNLKI menunjukkan adanya peningkatan indeks literasi dan inklusi keuangan namun masih banyak ditemukan masyarakat yang belum melek keuangan. Berdasarkan survei yang dilakukan oleh OJK pada tahun 2013, menunjukkan tingkat literasi keuangan penduduk Indonesia dibagi menjadi empat bagian, yaitu:

1) Well literate $(21,84 \%)$, yakni memiliki pengetahuan dan keyakinan tentang lembaga jasa keuangan serta produk jasa keuangan, termasuk fitur manfaat dan risiko, hak dan kewajiban terkait produk dan jasa keuangan, serta memiliki keterampilan dalam menggunakan produk dan jasa keuangan,

2) Sufficient literate $(75,69 \%)$, memiliki pengetahuan dan keyakinan tentang lembaga jasa keuangan serta produk dan jasa keuangan, termasuk fitur, manfaat dan risiko, hak dan kewajiban terkait produk dan jasa keuangan,

3) Less literate (2,06\%), hanya memiliki pengetahuan tentang lembaga jasa keuangan, produk dan jasa keuangan,

4) Not literate $(0,41 \%)$, tidak memiliki pengetahuan dan keyakinan terhadap lembaga jasa keuangan serta produk dan jasa keuangan, serta tidak memiliki keterampilan dalam menggunakan produk dan jasa keuangan. (OJK,2013).

Survei yang dilakukan OJK tahun 2013 ditemukan indeks literasi keuangan sebagai berikut: sebanyak 21 provinsi memiliki indeks literasi dibawah rata-rata. Dikatakan dibawah rata-rata karena kurang dari rata-rata nasional yaitu sebesar 29.7 persen. Indeks Literasi Keuangan 21 provinsi dapat dilihat pada tabel 1 . berikut: 
Tabel 1. Indeks Literasi Keuangan dibawa Rata-Rata Nasional

\begin{tabular}{|c|l|c|}
\hline No & \multicolumn{1}{|c|}{ Provinsi } & $\begin{array}{c}\text { Indeks Literasi Keuangan } \\
(\%)\end{array}$ \\
\hline 1 & Bangka Belitung & 29.5 \\
\hline 2 & Riau & 29.5 \\
\hline 3 & Sulawesi Utara & 28.7 \\
\hline 4 & Sulawesi Selatan & 28.4 \\
\hline 5 & Nusa Tenggara Timur & 28.0 \\
\hline 6 & Bengkulu & 27.6 \\
\hline 7 & Sumatera Barat & 27.3 \\
\hline 8 & Maluku Utara & 27.3 \\
\hline 9 & Sulawesi Barat & 26.9 \\
\hline 10 & Lampung & 26.9 \\
\hline 11 & Jambi & 26.9 \\
\hline 12 & Kalimantan Utara & 26.5 \\
\hline 13 & Sulawesi Tenggara & 26.5 \\
\hline 14 & Kalimantan Tengah & 26.2 \\
\hline 15 & Maluku & 26.2 \\
\hline 16 & Kalimantan Selatan & 23.3 \\
\hline 17 & Gorontalo & 23.3 \\
\hline 18 & Sulawesi Tengah & 22.5 \\
\hline 19 & Papua & 22.2 \\
\hline 20 & Nusa Tenggara Barat & 21.5 \\
\hline 21 & Papua Barat & 19.3 \\
\hline
\end{tabular}

Sumber: OJK, SNLKI (2017)

Provinsi Nusa Tenggara Timur merupakan salah satu provinsi yang menduduki peringkat lima yang memiliki indeks literasi dibawah rata-rata yaitu 28,0 persen. Hal ini berarti dari setiap 100 penduduk NTT hanya 28 orang yang memiliki indeks literasi yang tinggi (well literate). Hal ini akan mempengaruhi akses masyarakat NTT terhadap lembaga keuangan. Keterkaitan antara literasi keuangan dan akses masyarakat terhadap lembaga keuangan membuktikan bahwa literasi keuangan memiliki peran yang sangat penting untuk masyarakat agar dapat menuju pada kesejahteraan keuangan. Selain itu, literasi keuangan mempemudah individu dan pelaku usaha dalam mengelola keuangannya.

Perdagangan merupakan salah satu sektor yang mampu menyumbangkan pendapatan bagi masyarakat di Nusa Tenggara Timur. Melalui usaha dagang masyarakat NTT mampu menciptakan peluang untuk menghasilkan pendapatan. Salah satunya adalah pasar, pasar merupakan tempat yang banyak membuka peluang usaha untuk masyarakat, namun peluang usaha yang besar tersebut tidak menutupi kenyataan bahwa yang terjadi adalah pelaku usaha di pasar hampir seluruhnya menghadapi masalah yang sama yaitu permodalan.

Permasalahan permodalan merupakan permasalahan umum yang sering dihadapi oleh para pedagang di pasar. Kondisi literasi keuangan yang rendah membuat pedagang di pasar sering terjebak untuk meminjam pada orang-orang yang memiliki kelebihan modal sebagai sumber modal utama mereka. Selain itu karena akses mereka terhadap lembaga keuangan sangat minim sehingga masih banyak cara tradisional dalam menyimpan uang salah satunya adalah dengan menyimpannya di rumah dan tidak menggunakan poduk dan jasa lembaga keuangan. 
Fenomena konkret yang terjadi adalah masalah permodalan yang hadapi pedagang di Pasar Oesapa. Banyak pedagang di Pasar Oesapa, terjebak pada beberapa koperasi harian dan pada orang yang memiliki memiliki kelebihan dana yang dipinjamkan dengan perhitungan seperti sistem koperasi. Kondisi terparah dari kurangnya literasi keuangan di Pasar Oesapa adalah bangkrutnya usaha yang mereka rintis karena tidak sanggup membayar atau melunasi pinjaman-pinjaman yang mereka lakukan. Hal ini sejalan dengan penelitian yang dilakukan oleh Aribawa (2016) bahwa literasi keuangan berpengaruh terhadap kinerja dan keberlangsungan usaha.

Pedagang di pasar Oesapa digolongkan kedalam beberapa jenis yaitu pedagang yang memiliki kios, pedagang berlapak dan pedagang harian. Klasifikasi pedagang tersebut didapat dilihat pada tabel 2 berikut:

Tabel 2. Data Klasifikasi Pedagang di Pasar Oesapa

\begin{tabular}{|c|l|c|}
\hline No & \multicolumn{1}{|c|}{ Jenis } & Jumlah \\
\hline 1 & Kios & 159 \\
\hline 2 & Lapak & 16 \\
\hline & a. Ayam potong & 1 \\
\hline & b. Daging babi & 112 \\
\hline & c. Ikan & 12 \\
\hline & d. Daging ayam & 9 \\
\hline & e. Buah-buahan & 128 \\
\hline & f. Sayur mayur dan bawang & 1 \\
\hline & g. Daging sapi & 4 \\
\hline & h. Pakaian RB & 7 \\
\hline & i. Lapak penjual minuman & 2 \\
\hline & j. Ikan kering & 3 \\
\hline & k. Mol bumbu & 6 \\
\hline & l. Mol kelapa & 1 \\
\hline & m. Kaset & 1 \\
\hline & n. Bakso & 4 \\
\hline & o. Nasi & 268 \\
\hline 3 & Penjual Harian & 72 \\
\hline 4 & Kios di bangun di tanah sewaan & 17 \\
\hline 5 & Kios yang di kelola LPM Kel- & \\
\hline & Oesapa & 823 \\
\hline & Total & \\
\hline
\end{tabular}

Sumber: Pengelola Pasar Oesapa, 2018

Berdasarkan observasi awal yang dilakukan hampir semua pedagang yang harian dan pedagang yang memiliki lapak di pasar Oesapa terjebak pada koperasi harian dan mengikuti arisan serta meminjam uang pada orang yang kelebihan dana kemudian uang yang dipinjamkan tersebut bukan hanya digunakan untuk modal usaha tetapi lebih banyak untuk konsumsi sendiri. Berdasarkan fenomena yang terjadi, maka perlu diteliti indikator-indikator apa saja yang membentuk tingkat literasi keuangan Pedagang di Pasar Oesapa dan bagaimana tingkat literasi meraka. Berdasarkan Survei yang dilakuakan OJK tahun 2016 perhitungan indeks literasi keuangan menggunakan lima komponen yaitu pengetahuan keuangan, keterampilan keuangan, keyakinan keuangan, sikap keuangan dan perilaku keuangan. Namun, pada penelitian betujuan untuk mengetahui tingkat literasi keuangan pedagang di Pasar Oesapa berdasarkan indikator atau komponen pengetahuan keuangan, perilaku keuangan, sikap keuangan dan tanggapan teknologi keuangan. 


\section{TINJAUAN PUSTAKA \\ Literasi Keuangan}

Semakin banyak negara yang menyusun strategi nasional literasi keuangan untuk mewujudkan kesejahteraan masyarakat. Tingkat literasi yang memadai dari masyarakat merupakan salah satu indikator tingkat kesejahteraan masyarakat. Setiap masyarakat perlu diberikan kesadaran tentang pentingnya literasi keuangan dalam mencapai kesejahteraan hidupnya dalam jangka panjang. Hal tersebut pada akhirnya akan diikuti dengan meningkatnya permintaan program edukasi keuangan oleh masyarakat dan seluruh pemangku kepentingan akan termotivasi untuk menyediakan program edukasi keuangan sesuai kebutuhan konsumen dan masyarakat (Soetiono dan Setiawan, 2018:47).

Literasi keuangan meliputi kesadaran dan pengetahuan akan instrument keuangan dan aplikasinya didalam bisnis dan kehidupannya (Huston, 2010). Sementara Rozari (2016) menyebutkan bahwa literasi keuangan adalah rangkaian proses atau aktivitas untuk meningkatkan pengetahuan, keyakinan dan keterampilan konsumen dan masyarakat luas sehingga mereka mampu mengelola keuangan dengan lebih baik.

The Association of Chartered Certified Accountants dalam Aribawa (2016) menyatakan bahwa literasi keuangan mencakup pengetahuan mengenai konsep keuangan, kemampuan memahami komunikasi mengenai konsep keuangan, kecakapan mengelola keuangan pribadi/perusahaan dan kemampuan melakukan keputusan keuangan dalam situasi tertentu. Menurut Peraturan Otoritas Jasa Keuangan, literasi keuangan adalah pengetahuan, keterampilan dan keyakinan yang mempengaruhi sikap dan perilaku untuk meningkatkan kualitas pengambilan keputusan dan pengelolaan keuangan dalam rangka mencapai kesejahteraan.

Berdasarkan pendapat-pendapat terdahulu dapat didefinisikan bahwa literasi keuangan adalah kesadaran, pengetahuan, keterampilan, keyakinan yang didalamnya mencakup seluruh proses atau aktivitas untuk meningkatkan kesadaran atau keyakinan masyarakat dan mempengaruhi sikap dan perilaku mereka dalam mengambil keputusan keuangan untuk mencapai kesejahteraan.

\section{Komponen Literasi Keuangan}

OECD menyebutkan bahwa literasi keuangan adalah combination of awareness, knowledge, skills, attitude and behaviours necessary to make sound financial decisions and ultimately achieve individual financial well being. Hal ini menunjukkan bahwa seseorang memerlukan literasi keuangan yang terdiri dari lima elemen utama, yaitu kesadaran keuangan, pengetahuan keuangan, keterampilan keuangan, sikap keuangan dan perilaku keuangan, untuk dapat mengambil keputusan keuangan dan mencapai kesejahteraan.

Lima komponen pembentuk literasi keuangan tersebut diuraikan sebagai berikut:

(a) Komponen pertama, yaitu pengetahuan keuangan berhubungan dengan tingkat pemahaman individu akan lembaga keuangan formal dan produk dan layanan keuangan termasuk karakteristik produk dan layanan keuangan, yaitu risiko, manfaat serta hak dan kewajibannya sebagai konsumen;

(b) Komponen kedua, yaitu keterampilan keuangan merupakan kemampuan individu untuk melakukan perhitungan sederhana, termasuk dalam menghitung return dari produk dan layanan keuangan (bunga);

(c) Komponen ketiga, yaitu keyakinan keuangan kepercayaan individu terhadap lembaga keuangan formal, kepercayaan dalam menggunakan produk dan dan jasa keuangan dan kepercayaan dalam mengelola keuangannya;

(d) Komponen keempat, yaitu sikap keuangan yang berhubungan dengan sikap seseorang dalam masalah keuangan, misalnya sikapnya dalam membuat rencana keuangan pribadi;

(e) Komponen kelima, yaitu perilaku keuangan berhubungan dengan tujuan menggunakan produk dan upaya setiap orang dalam mencapai tujuan keuangan. 


\section{Tingkatan Literasi Keuangan}

OJK (2013) menjelaskan terdapat tingkatan literasi keuangan seseorang yang diklasifikasikan menjadi beberapa jenis tingkatan, antara lain:

1. Well Literate; Di tahap ini, seseorang mempunyai pengetahuan dan keyakinan tentang lembaga keuangan dan juga produk atau jasa keuangan, termasuk fitur, manfaat dan risiko, hak dan kewajiban terkait produk dan jasa lembaga keuangan serta juga mempunyai keterampilan dalam memakai produk dan jasa keuangan.

2. Suff Literate; Ditahap ini, seseorang mempunyai pengetahuan dan keyakinan tentang lembaga jasa keuangan dan juga produk dan jasa keuangan termasuk fitur, manfaat dan risiko, hak dan kewajiban terkait produk dan jasa keuangan.

3. Less Literate ; Ditahap ini, seseorang hanya mempunyai pengetahuan tentang lembaga jasa keuangan, produk dan jasa keuangan.

4. Not Literate; Di tahap ini, seseorang tidak mempunyai pengetahuan dan keyakinan tentang lembaga jasa keuangan dan juga produk serta jasa keuangan, serta tidak mempunyai keterampilan dalam memakai produk dan kasa keuangan.

\section{Inisiatif Nasional tentang Literasi Keuangan}

Dalam rangka menciptakan sistem perbankan yang sehat, kuat dan efisien guna menciptakan kestabilan sistem keuangan dalam rangka membantu pertumbuhan ekonomi nasional, Bank Indonesia pada 2004 telah mengeluarkan 16 Arsitektur Perbankan Indonesia (API) sebagai suatu kerangka menyeluruh arah kebijakan pengembangan industri perbankan Indonesia ke depan (BI,2004).

Salah satu pilar API adalah program peningkatan perlindungan nasabah dalam rangka mewujudkan pemberdayaan dan perlindungan konsumen jasa perbankan. Salah satu program dari pilar tersebut adalah mempromosikan edukasi untuk nasabah perbankan, yaitu dengan mendorong bankbank untuk melakukan edukasi kepada nasabah mengenai produk-produk finansial dan meningkatkan kegiatan edukasi mengenai perbankan syariah.

Arsitektur Perbankan Indonesia memiliki enam pilar utama untuk mewujudkan sistem perbankan yang sehat, kuat dan efisien. Salah satu pilar tersebut adalah perlindungan nasabah termasuk pemberian informasi dan edukasi masyarakat dibidang perbankan.

Edukasi yang dilakukan pada intinya merupakan pemberian informasi dan pemahaman kepada masyarakat mengenai fungsi dan kegiatan usaha bank, serta produk dan jasa yang ditawarkan bank. Edukasi dalam hal ini diharapkan dapat memfasilitasi pemberian informasi yang cukup kepada masyarakat sebelum mereka melakukan interaksi dengan bank guna menghindari terjadinya kesenjangan informasi pada pemanfaatan produk dan jasa perbankan yang dapat menyebabkan timbulnya permasalahan antar bank dengan nasabah di kemudian hari.

\section{Strategi Nasional Literasi Keuangan Indonesia}

Perkembangan dalam sistem keuangan dan pesatnya kemajuan di bidang teknologi informasi telah menjadikan literasi sebagai key life skill bagi setiap individu. Oleh karena itu, beberapa negara telah menyusun strategi nasional literasi keuangan sebagai guidelines bagi regulator di bidang keuangan, industri jasa keuangan dan para pemangku kepentingan lainnya untuk dapat melaksanakan program literasi keuangan secara terstruktur dan sistematis.

Otoritas Jasa Keuangan dan lembaga jasa keuangan serta asosiasi industri jasa keuangan berperan penting dalam meningkatkan pengetahuan, pemahaman serta penggunaan produk dan jasa keuangan oleh masyarakat. Untuk itu, Otoritas Jasa Keuangan memandang perlu menyusun Strategi Nasional Literasi Keuangan Indonesia yang bersifat komprenhensif. 
Presiden Republik Indonesia telah mengeluarkan Strategi Nasional Literasi Keuangan Indonesia pada 19 November 2013 untuk digunakan sebagai pedoman bagi regulator keuangan, lembaga jasa keuangan dan seluruh stakeholders dalam rangka meningkatkan kesejahteraan masyarakat. Hal ini penting agar upaya peningkatan literasi keuangan masyarakat berlangsung dengan lebih terstruktur dan sistematis. Pada 2017, OJK meluncurkan Strategi Nasional Literasi Keuangan Indonesia (Revisit, 2017) yang merupakan penyempurnaan dari strategi sebelumnya. Penyempurnaan tersebut diperlukan sebagai hasil evaluasi dan perkembangan yang terjadi di industri jasa keuangan (OJK, 2017).

Hasil evaluasi kegiatan literasi keuangan dan edukasi keuangan tahun 2013-2015 menunjukkan bahwa selama tiga tahun terakhir, lebih dari setengah lokasi pelaksanaan edukasi oleh lembaga jasa keuangan masih dilakukan di Pulau Jawa. Selain itu, kelompok sasaran program edukasi masih didominasi oleh pelajar dan mahasiswa dan banyak lembaga jasa keuangan yang masih memberikan materi seputar lembaga jasa keuangan dan produk-produk keuangan. Masih sedikit lembaga jasa keuangan yang memberikan mengajarkan konsumen dan masyarakat tentang manfaat dan risiko produk keuangan serta hak dan kewajiban sebagai konsumen.

Perkembangan teknologi informasi, produk dan layanan jasa keuangan yang semakin kompleks, masih rendahnya tingkat literasi dan inklusi keuangan berdasarkan hasil survei nasional dan inklusi keuangan 2016 dan keberadaan Peraturan Presiden Nomor 82 Tahun 2016 tentang Strategi Nasional Keuangan Inklusif, juga menjadi alasan pentingnya dilakukan penyempurnaan terhadap Strategi Nasional Literasi Keuangan Indonesia. Selain itu, terdapat penambahan aspek sikap dan perilaku keuangan pada literasi keuangan.

Strategi Nasional Literasi Keuangan harus dilengkapi dengan tujuan yang jelas untuk memungkinkan dilakukannya monitoring dan evaluasi. Dengan outcome yang spesifik, setiap program dapat dievaluasi bagaimana program tersebut memberikan kontribusi dalam pencapaian outcomes. Salah satu perubahan mendasar dari SNLKI (Revisit,2017) adalah adanya perubahan tujuan dari strategi nasional untuk mengubah perilaku keuangan seseorang, dan bukan hanya untuk meningkatkan pengetahuan keuangan semata. Hal ini, sejalan dengan praktek internasional yang menyebutkan bahwa tujuan strategi nasional di 16 dari 18 negara adalah untuk mengubah perilaku keuangan (World Bank, 2016, Soetiono dan Setiawan, 2018).

Visi Strategi Nasional Literasi Keuangan (Revisit 2017) adalah "mewujudkan masyarakat Indonesia yang memiliki indeks literasi keuangan yang tinggi (well literare) sehingga dapat memanfaatkan produk dan jasa keuangan yang sesuai untuk mencapai kesejahteraan keuangan yang berkelanjutan". Visi dalam strategi ini memperlihatkan tujuan akhir dari strategi nasional adalah meningkatkan kesejahteraan keuangan masyarakat melalui kemampuan untuk memanfaatkan produk dan layanan jasa keuangan yang sesuai dengan kebutuhan dan kemampuan.

Melalui implementasi Strategi Nasional Literasi Keuangan Indonesia, diharapkan indeks literasi dan inklusi keuangan mengalami peningkatan secara bertahap dalam jangka panjang. Tujuan untuk mencapai masyarakat Indonesia yang well literate di bidang keuangan harus dicapai melalui pendekatan kelompok sasaran, sektoral, geografi dan tematik. Pendekatan kelompok sasaran dan geografi dipernukan karena terdapat kelompok masyarakat tertentu atau wilayah yang lebih rentan (vulnerable). Sementara itu, pendekatan sektoral dari masing-masing sektor jasa keuangan diperlukan karena tingkat literasi dari masing-masing sektor jasa keuangan berbeda satu sama lainnya, sedangkan pendekatan tematik diperlukan untuk meng-address beberapa tema khusus yang memerlukan program edukasi yang lebih intensif, misalnya edukasi keuangan syariah dan edukasi tentang waspada investasi. 


\section{METODE PENELITIAN}

Jenis penelitian ini adalah penelitian deskriptif kuantitatif dengan pendekatan menggunakan metode survei yaitu metode penelitian yang digunakan untuk mendapatkan data yang terjadi di masa lampau atau saat ini, tentang keyakinan, pendapat karakteristik, perilaku, hubungan variabel dan untuk menguji beberapa hipotesis tentang variabel dari sampel yang diambil dari populasi tertentu, dengan pengamatan yang tidak mendalam dan hasil yang cenderung untuk digeneralisasikan (Sugiyono, 2016: $81)$.

Penelitian ini dilakukan pada bulan Maret-April 2019, bertempat di Pasar Oesapa Keluruhan Oesapa, Kecamatan Kelapa Lima, NTT. Jenis data dalam penelitian ini adalah data kualitatif, atau data bersifat non-numerik atau menggunakan kata-kata untuk mengambarkan objek atau situasi sosial yang diteliti. Dalam hal ini data kualitatif yang dimaksud adalah data yang diperoleh dari penyebaran kuesioner. Sumber data yang digunakan dalam penelitian ini adalah data primer yaitu data yang diperoleh secara langsung oleh peneliti dari penyebaran dan pengisian kuesioner. Data sekunder dalam penelitian ini adalah data yang diperoleh secara tidak langsung atau data yang tidak diolah oleh peneliti sendiri, misalnya data ang diperoleh melalui jurnal, buku, publikasi dari instansi-instansi terkait.

Populasi dalam penelitian ini adalah seluruh pedagang di Pasar Oesapa yang berjumlah 823 orang. Teknik pengambilan sampel dilakukan dengan menggunakan metode Slovin sehingga sampel dalam penelitian ini sebanyak 90 pedagang pasar. Teknik pengumpulan data dalam penelitian dilakukan dengan observasi, kuesioner dan wawancara. Kuesioner yang digunakan dalam penelitian ini adalah kuesioner dengan model Skala Likert. Skala Likert adalah skala yang digunakan untuk mengukur sikap, pendapat, dan pesepsi seseorang atau sekelompok orang tentang fenomena sosial (Sugiyono, 2016: 168). Skala likert ini mempunyai tingkatan skor penilaian dari 5 dengan pernyataan sangat setuju sampe 1 dengan pernyataan sangat tidak setuju.

\section{HASIL DAN PEMBAHASAN}

Untuk mengukur tingkat literasi keuangan pedagang di Pasar Oesapa digunakan tiga indikator pengukuran, yaitu : 1) pengetahuan keuangan ; 2) perilaku keuangan dan 3) sikap keuangan. Adapun indikator tambahan dalam penelitian ini adalah tanggapan para pedagang mengenai teknologi perbankan saat ini. Untuk menentukan kriteria literasi keuangan, peneliti menggunakan kriteria yang ditentukan Chen \& Volpe (1998), sebagai berikut :

a. Literasi Keuangan memiliki nilai $<60 \%$ dikategorikan rendah.

b. Literasi Keuangan memiliki nilai antara $60 \%$ - $79 \%$ dikategorikan sedang.

c. Literasi Keuangan memiliki nilai $>80 \%$ dikategorikan tinggi. 


\section{Indikator Pengetahuan Keuangan}

Pengetahuan keuangan berhubungan dengan tingkat pemahaman individu akan lembaga keuangan formal,produk dan layanan keuangan. Berikut hasil penelitian literasi keuangan pedagang di Pasar Oesapa berdasarkan indikator pengetahuan keuangan, ditunjukkan tabel 3 berikut :

Tabel 3. Skoring dan Persentasi Indikator Pengetahuan Keuangan

\begin{tabular}{|c|c|c|c|c|c|c|c|c|}
\hline \multirow[t]{2}{*}{ Indikator } & \multirow[t]{2}{*}{ Item } & \multicolumn{5}{|c|}{ Jawaban Responden } & \multirow[t]{2}{*}{ Skor } & \multirow[t]{2}{*}{ Persentase } \\
\hline & & SS & $\mathrm{S}$ & $\mathrm{N}$ & TS & STS & & \\
\hline \multirow{13}{*}{$\begin{array}{l}\text { Pengetahuan } \\
\text { Keuangan }\end{array}$} & 1 & 14.4 & 56.7 & 6.7 & 18.9 & 3.3 & 360 & 72 \\
\hline & 2 & 28.9 & 58.9 & 4.4 & 4.4 & 3.3 & 405.4 & 81.08 \\
\hline & 3 & 17.8 & 57.8 & 10 & 11.1 & 3.3 & 375.7 & 75.14 \\
\hline & 4 & 46.7 & 47.8 & 0 & 2.2 & 3.3 & 432.4 & 86.48 \\
\hline & 5 & 22.2 & 31.1 & 5.6 & 24.4 & 16.7 & 317.7 & 63.54 \\
\hline & 6 & 30 & 34.4 & 14.4 & 14.4 & 6.7 & 366.3 & 73.26 \\
\hline & 7 & 17.8 & 41.1 & 12.2 & 21.1 & 7.8 & 340 & 68 \\
\hline & 8 & 11.1 & 45.6 & 10 & 25.6 & 7.8 & 326.9 & 65.38 \\
\hline & 9 & 6.7 & 25.6 & 15.6 & 42.2 & 10 & 277.1 & 55.42 \\
\hline & 10 & 10 & 33.3 & 20 & 27.8 & 8.9 & 307.7 & 61.54 \\
\hline & 11 & 12.2 & 31.1 & 16.7 & 31.1 & 8.9 & 306.6 & 61.32 \\
\hline & 12 & 12.2 & 27.8 & 16.7 & 38.9 & 4.4 & 304.5 & 60.9 \\
\hline & 13 & 11.1 & 36.7 & 17.8 & 24.4 & 10 & 314.5 & 62.9 \\
\hline \multicolumn{8}{|l|}{ Total Persentasi } & 886.96 \\
\hline \multicolumn{8}{|l|}{$\%$ Rata-Rata } & 68.23 \\
\hline
\end{tabular}

Sumber: Data Diolah, 2019

Pengetahuan Keuangan memilki persen rata-rata sebesar 68.23 persen. Hal ini berarti pengetahuan keuangan pedagang di Pasar Oesapa berada pada kategori sedang, yang berarti tingkat pemahaman individu akan lembaga keuangan formal dan produk dan layanan keuangan termasuk karakteristik produk dan layanan keuangan, yaitu risiko, manfaat serta hak dan kewajibannya sebagai konsumen berada pada tingkat sedang atau hanya sekedar mengetahui dan menyakini.

\section{Indikator Perilaku Keuangan}

Perilaku keuangan berhubungan dengan tujuan menggunakan produk dan upaya setiap orang dalam mencapai tujuan keuangan. Berikut hasil penelitian literasi keuangan pedagang di Pasar Oesapa berdasarkan indikator perilaku pengetahuan ditunjukkan tabel 4 berikut :

Tabel 4. Skoring dan Persentasi Perilaku Keuangan

\begin{tabular}{|c|c|c|c|c|c|c|c|c|}
\hline \multirow[t]{2}{*}{ Indikator } & \multirow[t]{2}{*}{ Item } & \multicolumn{5}{|c|}{ Jawaban Responden } & \multirow[t]{2}{*}{ Skor } & \multirow[t]{2}{*}{ Persentase } \\
\hline & & SS & $\mathrm{S}$ & $\mathrm{N}$ & TS & STS & & \\
\hline \multirow{4}{*}{ Perilaku Keuangan } & 14 & 15.6 & 26.7 & 12.2 & 38.9 & 6.7 & 305.9 & 61.18 \\
\hline & 15 & 18.9 & 23.3 & 12.2 & 38.9 & 6.7 & 308.8 & 61.76 \\
\hline & 16 & 28.9 & 52.2 & 10 & 6.7 & 2.2 & 398.9 & 79.78 \\
\hline & 17 & 4.4 & 21.1 & 11.1 & 24.4 & 38.9 & 227.4 & 45.48 \\
\hline \multicolumn{8}{|l|}{ Total Persentasi } & 248.20 \\
\hline \multicolumn{8}{|l|}{ \% Rata-Rata } & 62.05 \\
\hline
\end{tabular}

Sumber: Data Diolah, 2019 
Indikator Perilaku keuangan memiliki persen rata-rata sebesar 62.05 persen yang berarti perilaku keuangan pedagang di pasar Oesapa atau tujuan keuangan dan upaya mencapai tujuan keuangan mereka berada pada kategori sedang. Hal ini menunjukkan bahwa pedagang di Pasar Oesapa cukup berusaha untuk mencapai tujuan keuangan mereka.

\section{Indikator Sikap Keuangan}

Sikap keuangan berhubungan dengan sikap seseorang dalam masalah keuangan. Berikut hasil penelitian literasi keuangan pedagang di Pasar Oesapa berdasarkan indikator sikap keuangan ditunjukkan tabel 5 berikut :

Tabel 5. Skoring dan Persentasi Sikap Keuangan

\begin{tabular}{|c|c|c|c|c|c|c|c|c|}
\hline \multirow[t]{2}{*}{ Indikator } & \multirow[t]{2}{*}{ Item } & \multicolumn{5}{|c|}{ Jawaban Responden } & \multirow[t]{2}{*}{ Skor } & \multirow[t]{2}{*}{ Persentase } \\
\hline & & SS & $S$ & $\mathrm{~N}$ & TS & STS & & \\
\hline \multirow{4}{*}{ Sikap Keuangan } & 18 & 23.3 & 44.4 & 23.3 & 5.6 & 3.3 & 378.5 & 75.7 \\
\hline & 19 & 13.3 & 32.2 & 8.9 & 14.4 & 31.1 & 281.9 & 56.38 \\
\hline & 20 & 12.2 & 44.4 & 15.6 & 20 & 7.8 & 333.2 & 66.64 \\
\hline & 21 & 4.4 & 17.8 & 12.2 & 24.4 & 41.1 & 219.7 & 43.94 \\
\hline \multicolumn{8}{|l|}{ Total Persentasi } & 242.66 \\
\hline \multicolumn{8}{|l|}{$\%$ Rata-Rata } & 60.67 \\
\hline
\end{tabular}

Sumber: Data Diolah, 2019

Hasil penelitian menunjukkan bahwa sikap keuangan pedagang di Pasar Oesapa memiliki ratarata persentasi sebesar 60.67 persen yang berarti sikap pedagang di Pasar Oesapa dalam menghadapi masalah keuangan berada pada kategori sedang.

\section{Indikator Tanggapan Teknologi Perbankan}

Indikator tanggapan teknologi perbankan menunjukkan bagaimana seseorang memanfaatkan teknologi untuk mempermudah transaksi perbankan. Berikut hasil penelitian terhadap indikator tanggapan teknologi perbankan pedagang di Pasar Oesapa berdasarkan indikator tanggapan teknologi perbankan ditunjukkan tabel 6 berikut :

Tabel 6. Skoring dan Persentasi Tanggapan Teknologi Perbankan

\begin{tabular}{|c|c|c|c|c|c|c|c|c|}
\hline \multirow[t]{2}{*}{ Indikator } & \multirow[t]{2}{*}{ Item } & \multicolumn{5}{|c|}{ Jawaban Responden } & \multirow[t]{2}{*}{ Skor } & \multirow[t]{2}{*}{ Persentase } \\
\hline & & SS & $\mathrm{S}$ & $\mathrm{N}$ & TS & STS & & \\
\hline \multirow{5}{*}{$\begin{array}{l}\text { Tanggapan Teknologi } \\
\text { Perbankan }\end{array}$} & 22 & 24.4 & 45.6 & 8.9 & 13.3 & 7.8 & 365.5 & 73 \\
\hline & 23 & 7.8 & 8.9 & 14.4 & 54.4 & 14.4 & 241 & 48.2 \\
\hline & 24 & 4.4 & 16.7 & 13.3 & 51.1 & 14.4 & 245.3 & 49.06 \\
\hline & 25 & 5.6 & 15.6 & 14.4 & 50 & 14.4 & 248 & 49.6 \\
\hline & 26 & 23.3 & 24.4 & 8.9 & 27.8 & 15.6 & 312 & 62.4 \\
\hline \multicolumn{8}{|l|}{ Total Presentasi } & 282 \\
\hline \multicolumn{8}{|l|}{$\%$ Rata-Rata } & 56.47 \\
\hline
\end{tabular}

Sumber: Data Diolah, 2019

Indikator tanggapan pedagang di Pasar Oesapa mengenai perbankan digital (teknologi perbankan) saat ini memiliki persentasi sebesar 56.47 persen. Hal ini berarti pemahaman/tanggapan pedagang di Pasar Oesapa mengenai teknologi keuangan saat ini berada pada katergori rendah. Hal ini dikarenakan pedagang di Pasar Oesapa belum familiar atau tidak familiar dengan fitur-fitur online yang digunakan 
perbankan saat ini. Selain tidak familiar dengan fitur online, jika ditinjau dari usia pedagang di Pasar Oesapa adalah berusia 37-46 tahun yang mana pada usia ini adalah usia yang belum produktif menggunakan intenet sehingga belum mampu menggunakan fitur-fitur online. Alasan lain yang mungkin menyebabkan rendahnya tanggapan pedagang di Pasar Oesapa adalah rendahnya penetrasi internet di Nusa Tenggara Timur. Oleh karena itu, mereka lebih memilih untuk bertransaksi dengan datang langsung ke bank atau bertransaksi online tetapi dengan meminta bantuan orang lain (anak) yang lebih mengerti dalam mengaplikasikan fitur-fitur online yang disediakan lembaga keuangan.

Berdasarkan hasil analisis secara keseluruhan ditemukan literasi keuangan pedagang di Pasar Oesapa memiliki persentasi sebesar 63.85 persen, artinya literasi keuangan pedagang di Pasar Oesapa berada pada kriteria sedang. Hal ini mengindikasikan bahwa pedagang di Pasar Oesapa memiliki pengetahuan dan keyakinan tentang lembaga jasa keuangan dan juga produk dan jasa keuangan termasuk fitur, manfaat dan risiko, hak dan kewajiban terkait produk dan jasa keuangan namun belum disertai dengan keterampilan dalam menggunakan produk dan jasa lembaga keuangan tersebut.

Kategori sedang Pedagang di Pasar Oesapa sama dengan kategori sedang pedagang pada Pasar Tradisional di Kota Denpasar. Berdasarkan penelitian yang dilakukan Ayu dan Nyoman tahun 2018 pedagang pada pasar tradisional di Bali memiliki kategori sedang berdasarkan hasil penelitian mereka terhadap variabel yang paling menentukan tingkat literasi yaitu tingkat pendidikan dan lamanya usaha. Sedangakan, jenis kelamin tidak berpengaruh positif dan signifikan terhadap tingkat literasi keuangan. Penelitian yang dilakukan Yuwono, Suharjo, Sanim, dan Nurmalina tahun 2017 mengungkapkan bahwa pengetahuan kelompok tani di Jawa Timur, Jawa Barat dan Jawa Tengah tentang perbankan dan asuransi adalah 100 persen dan 80 persen sedangkan untuk mesin ATM sebesar 94 persen. Jika dibandingkan dengan tingkat literasi keuangan kategori sedang pedagang di Pasar Oesapa maka akan sangat jauh karena pengetahuan pedangang di Pasar Oesapa tentang bank dan asuransi hanya mencapai 56.7 persen dan 41.1 persen. Berdasarkan penelitian tersebut semakin tinggi pengetahuan tentang lembaga keuangan makan semakin tinggi penggunaan produk dan jasa lembaga keuangan.

\section{PENUTUP \\ Simpulan}

Secara keseluruhan berdasarkan indikator yang membentuk literasi keuangan maka dapat dikatakan bahwa literasi keuangan pedagang di Pasar Oesapa berada pada kategori sedang yang berarti pedagang di Pasar Oesapa hanya memiliki pengetahuan dan keyakinan terhadap lembaga keuangan formal namun tidak disertai dengan keterampilan mereka dalam menggunakan produk dan jasa lembaga keuangan tersebut. Jika ditinjau berdasarkan masing-masing indikator pembentuk literasi keuangan, maka literasi keuangan pedagang di Pasar Oesapa adalah pengetahuan keuangan pedagang Oesapa berada pada kategori sedang, yang berarti tingkat pemahaman individu akan lembaga keuangan formal dan produk dan layanan keuangan termasuk karakteristik produk dan layanan keuangan, yaitu risiko, manfaat serta hak dan kewajibannya sebagai konsumen berada pada tingkat sedang atau hana sekedar mengetahui dan menyakini. Perilaku keuangan berada pada kategori sedang yang beerarti upaya mereka untuk mencapai tujuan keuangan mereka berada dalam tingkatan sedang. Indikator sikap keuangan pedagang di Pasar Oesapa berada dalam tingkat sedang. Hal ini berarti upaya pedagang untuk menghadapi masalah keuangan mereka berada di tingkat sedang. Rata-rata pedagang di Pasar Oesapa telah memilki alternatif-alternatif untuk menghadapi masalah keuangan mereka. Pada indikator Tanggapan Tentang Perbankan digital berada pada tingkat rendah. Hal ini dikarenakan pedagang di Pasar Oesapa belum familiar atau tidak familiar dengan fitur-fitur online yang digunakan perbankan saat ini. Mereka lebih memilih untuk bertransaksi dengan datang langsung ke bank atau bertransaksi online tetapi dengan meminta bantuan orang lain (anak) yang lebih mengerti dari mereka. 


\section{Saran}

Para pedagang diharapkan tidak hanya memiliki pengetahuan atau tidak hanya sekedar mengetahui tentang lembaga keuangan itu penting saja tetapi harus diimbangi dengan keterampilan untuk menggunakan. Selain itu, dalam hal penggunaan keuangan sebaiknya ditentukan prioritas berdasarkan kebutuhan bukan keinginan agar pengeluaran dapat diminimalisir.

Bagi peneliti selanjutnya, penelitian ini hanya sebatas untuk mengetahui tentang tingkat literasi pedagang di Pasar Oesapa. Diharapkan pada penelitian selanjutnya dapat diteliti keterkaitan antara tingkat literasi terhadap variabel lain yang memungkinkan seperti akses atau faktor-faktor lainnya. Kemudian diharapkan penelitian ini diarahkan pada penelitian kualitatif atau mix method. Wawancara terbuka dan tertutup sangat disarankan untuk penelitian selanjutnya untuk melengkapi penelitian ini.

Bagi Lembaga Keuangan diharapkan untuk meningkatkan sosialisasi sosialisasi mengenai produk dan jasa lembaga keuangan agar mampu menjangkau pelaku-pelaku usaha kecil untuk meningkatkan pengetahuan mereka tentang lembaga keuangan beserta produk dan jasanya kemudian terampil dalam menggunakan produk dan jasa lembaga keuangan baik digital maupun konvensional.

\section{REFERENSI}

Akmal, Hariyatul. 2016. Analisis Tingkat Literasi Keuangan. Jurnal Ekonomi dan Bisnis Islam.Vol.1.No.2; pp 238-244.

Anggraeni, Dwi Birawani. 2015. Pengaruh Tingkat Literasi Keuangan Pemilik Usaha Terhadap Pengelolaan Keuangan Studi Kasus: UMKM Depok, Jurnal Vokasi Indonesia Vol.4.No.1: Halaman 43-50.

Aribawa, Dwitya.2016. Pengaruh Literasi Keuangan Terhadap Kinerja dan Keberlangsungan UMKM di Jawa Tengah, Jurnal Siasat Bisnis. Vol.20.No.1: Halaman 1-13

BI. 2014. Buku Saku Keuangan Inklusif.pdf. Diakses melalui www.bi.go.id pada tanggal 15 Maret 2019

.2014. Financial Literacy Baseline Survey. Diakses melalui www.bi.go.id pada tanggal 01 Maret 2019

Bonita ,A. P. Arantza dan Setiawina, N. Djinar. 2018. Analisis Determinan Tingkat Literasi Keuangan Pedagang Pada Pasar Tradisional Di Kota Denpasar, E-Jurnal EP Unud, 7[2]: 354-380 ISSN: 2303-0178

Chen, Haiyang dan Volpe,R. P. 1998. An Analysis of Personal Financial Literacy Among Collage Students. Financial Services Review, 7 (2). ISSN:1057-0810. Hal 107-128

Jati, Hironnymus. 2017. Pengetahuan Manajemen Bisnis, Literasi Keuangan dan Kinerja UMK Ekonomi Kreatif di Kabupaten Flores Timur.Seminar Nasional Riset Inovatif. ISBN: 978602-6428-11-0; Halaman 536-544

Kunt, Asli Demirguc, Klapper ,Leora dan Singer, Dorothe. 2017. Financial Inclusion and Inclusive Growth A Review of Recent Empirical Evidence. Policy Research Working Paper 8040

Kunt, Asli Demirguc dan Klapper .2012. Measuring Financial Inclusion The Global Findex Database. Policy Research Working Paper 6025

Lestari, Sri. 2015. Literasi Keuangan Serta Penggunaan Produk dan Jasa Lembaga Keuangan, Jurnal Fokus Bisnis. Vol.14.No.2; hal 14-24

Yuwono, Minto, Suharjo Budi, Sanin Bunasor, dan Nurmalina, Rita. 2017. Analisis Deskriptif Atas Literasi Keuangan Pada Kelompok Tani, Jurnal Ekonomi dan Keuangan.

Otoritas Jasa Keuangan. 2016. Peraturan Presiden Nomor 82 Tahun 2016. Diakses pada tanggal 22 Febuari 2019 melalui http://sikapiuangmu.ojk.go.id.

2017. Strategi Nasional Literasi Keuangan Indonesia(Revisit 2017). Diakses pada tanggal 01 Oktober 2018

melalui

http://www.ojk.go.id/id/beritadankegiatan/publikasi/Pages/StrategiNasional-Literasi- 
Keuangan-Indonesia(Revisit2017).aspx.

Rozari, Petrus E. de. 2016. Keuangan Inklusif: Kinerja Perbankan dan UMKM dalam Meningkatkan Perekonomian Daerah, Seminar Nasional Keuangan Inklusif FEB UNDANA

Soetiono, K.S dan Setiawan, Cecep, 2018. Literasi dan Inklusi Keuangan Indonesia. Depok: PT.Raja Grafindo Persada.

Sugiyono. 2016. Metode Penelitian Manajemen. Bandung: Alfabet. Cetakan-5.

Welly, Kardinal, Juwita. Analisis Pengaruh Literasi Keuangan Terhadap Keputusan Investasi di STIE Multi Data Palembang. Jurnal Ilmu Ekonomi, Manajemen. Hal. 1-16

Widayanti, Damayanti, Marwati.2017. Pengaruh Financial Literacy Terhadap Keberlangsungan Usaha (Business Sustainability) Pada UMKM Desa Jatisari, Jurnal Ilmiah Manajemen dan Bisnis. Vol.18. No.2. hal 153-163

$\mathrm{Xu}, \mathrm{Lisa}$ dan Zia, Bilal. 2012. Financial Literacy around the World:An Overview of the Evidence with Practical Suggestions for the Way Forward. Policy Research Working Paper 6107.

.2012. Financial Literacy around the World:An Overview of the Evidence with Practical Suggestions for the Way Forward. Policy Research Working Paper 6107.

Yuwono, Budi, Suharjo, Budi, Sanim, Bunasor, dan Nurmalina, Rita. 2017.

Analisis Deskriptif Atas Literasi Keuangan Pada kelompok Tani, Jurnal Ekonomi dan Keuangan. Vol1, No.3. Hal: 408-428. 